\title{
A Study of Work -Family Life Balancing Practices among Managerial Level Employees in Sri Lanka
}

By

C.K. Thenabadu

(GS/MC/2362/2004)

Thesis submitted to the University of Sri Jayewardenepura for the award of the degree of Master of Science in Management on

17.05.2010

M.Sc. Management degree program 


\section{CANDIDATE'S DECLARATION}

The work described in this thesis was carried out by me under the supervision of Prof. H.H.D.N.P. Opatha, Department of Human Resources Management of the University of Sri Jayewardenepura, and a report on this has not been submitted in whole or in part to any university or any other institution for another Degree/Diploma.

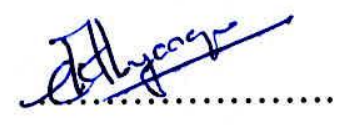

C.K. Thenbadu

(GS/MC/2362/2004) 


\section{SUPERVISOR'S DECLARATION}

I certify that the above statement made by the candidate is true and that this thesis is suitable for submission to the University for the purpose of evaluation.
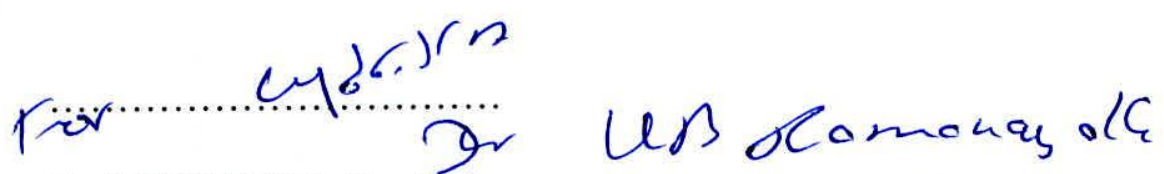

Prof. H.H.D.N.P. Opatha 17,052010

B.Sc (B.Ad.) Sp.(SJP); MSc (B.Ad.) HRM (SJP); MBA (Birmingham);Dip. PM\&IR (Cambridge Col.); Dip E.Eng(CPM), PhD HRM(Utara:UUM); D HRM (11U)

Supervisor of the Candidate

Professor of Human Resource Management on Merit

Department of Human Resources Management

University of Sri Jayewardenepura

Nugegoda. 


\section{ACKNOWLEDGEMENT}

At the very outset, I wish to express my gratitude to, Professor H.H.D.N.P. Opatha , the Supervisor of the theses, in the Department of Human Resources Management, University of Sri Jayewardenepura for providing me with valuable guidance and advices in carrying out this research successfully. I shall always remember his kindness, patience and the sacrifice of his valuable time, in discussing and evaluating my dissertation in the midst of his very busy work schedules.

My sincere appreciation goes to Dr. P.D. Nimal, The Coordinator, M.Sc Management Program, Faculty of Graduate Studies, University of Sri Jayawardenepura, Sri Lanka, for the guidance and assistance provided to me. I must also be grateful to Mr. K.H. Hemantha Kumara, Senior Lecturer, Department of Human Resources Management for guiding me in the right direction in doing the study. My special thanks go to Dr.U.B. Ramanayake, Senior Lecturer, Department of Business Administration for providing me with valuable guidance in carrying out this research successfully.

I would like to thank my mother and father for the continuous encouragement given to me to complete my entire M.Sc programme. I express my sincere gratitude to my husband for his wonderful support and encouragement and the enormous sacrifice he had to make during my studies. This work would not have been possible without the sincerer support 
and the enthusiasm given to me by my friends Dushan, Sisira, Sisila, Akila, Thilina, Kosala, Ranjith, Chaminda, Asanka and Yasith, Ruwan, Udaya and Gayani.

I must not forget the generous support and cooperation extended to me by $\mathrm{Mr}$. H. M. Densil, Deputy Commissioner, Colombo City Branch, Department of Inland Revenue I also express my gratitude to all respondents (Managers) who participated and gave interviews for data collection. 


\title{
A Study of Work -Family Life Balance Practices among Managerial Level Employees in Sri Lanka
}

\section{Changika Koomerinie Thenabdu (GS/MC/2362/2004)}

\begin{abstract}
It is no doubt that Human Resource Management plays a very critical role in managing the organizations towards its success. The workforce of the organization is being treated as the key resource among all the other resources due to its unique and exclusive features and this enables the organizations to gain sustainable competitive advantage over the others in the dynamic environment. The managerial employees of an organization play a strategic role in deriving the business and they are loaded with high career goals to be achieved by them. On the other hand there are various sets of personal life goals also to be achieved. Therefore the identification of practice of balancing the family life and work life in managerial level employees is essential since both depend on each others, personal life has an impact on working life and working life has an impact on personal life. Sri Lanka is still new to the work life balance concept and the present study has been carried out to evaluate the nature of work life balance, as experienced by managers in Sri Lankan context. Therefore, the theme of the study was : A Study of Work -Family Life Balance Practices among Managerial Level Employees in Sri Lanka. The objectives of the study were to investigate whether or not the Managerial Level employees consider the balance between work life and family life as important, to investigate reasons for their perceptions, to investigate how Sri Lankan
\end{abstract}


Managers at the public and private sector maintain the work and family balance, to identify the issues associated with balancing work and family in Sri Lankan managers both public and private sector, to identify organizational best practices in terms of dealing with work and family issues identified above and to compare how public and private sector organizations differ from each other with respect to the practices for balancing of work and family issues. This research was carried out based on a qualitative research strategy which was designed by using face to face discussion with randomly selected forty managerial level employees. The unit of analysis was at individual level. A structured questionnaire was used to gather the primary data. In order to secure the trustworthiness and the reliability of the information, thick description and triangulation methods were used. The type of this study is descriptive and explanatory. It was conducted in the natural setting with less interference of the researcher (non-contrived). The study is a cross-sectional in time. Findings of the study reveal that Managers (Respondents) agreed with the fact that they need to maintain a strong and a fair balance between the work and family life. Most of the Managers have a balanced work versus family relationship. But due to some shortfalls, there are instances that their family lives and professional lives have undergone with troublesome situations, where the reasons behind these are varied. It has also identified the steps taken by the government, organization, family and the individuals to maintain the work family balance. Further, there are different practices and common practices between the public and private sector organizations. Hence, there is no 'the practice' in balancing work and family life of a manager but there are 'practices' in balancing work life and a family life of a manager. 


\section{Table of Content}

Page No.

Acknowledgement

i

Abstract

iii

Table of Content

v

List of Tables

xvii

List of Figures

xviii

\section{CHAPTER 1:INTRODUCTION}

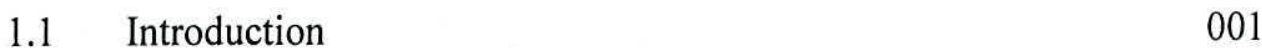

1.2 Background of the Study 001

$\begin{array}{lll}1.3 & \text { Problem Statement } & 003\end{array}$

$\begin{array}{lll}1.4 & \text { Research questions } & 005\end{array}$

1.5 Objective of the study 006

1.6 Significance of the study 006

$\begin{array}{lll}1.7 & \text { Research Methodology } & 010\end{array}$

$1.8 \quad$ Limitation of the study 011

$\begin{array}{lll}1.9 & \text { Structure of the report } & 012\end{array}$

$\begin{array}{lll}1.10 & \text { Summary } & 013\end{array}$

\section{CHAPTER 2: LITERATURE SURVEY}

$\begin{array}{lll}2.1 & \text { Introduction } & 014\end{array}$

$\begin{array}{lll}2.2 & \text { Work life and family life balance } & 014\end{array}$ 
2.2.1 Concept of a "Family" 014

2.2.2 Concept of a "Work" 016

$\begin{array}{ll}\text { 2.2.3 Work- Family Balance } & 017\end{array}$

2.2.4 Family Roles and Work Values 020

2.2.5 Importance of balancing both work and family life 021

2.2.6 Types of Work-Family Interface: In the Perspectives of Role Stress Theory and Role Enhancement Theory 024

2.2.6.1 Perspective of role stress theory 025

2.2.6.2 Perspective of role enhancement theory 026

2.2.6.3 Links between work-family interface and well-being 026

2.2.7 Family Resilience Theory and Work Family Balancing 028

2.2.8 Family, Work Impact on each Individual 029

2.3 Work Life and Family Life Imbalance 030

2.3.1 Work life - Family Life Imbalance 031

2.3.2 Barriers Impeding Work - Family Balance in Organizations 034

2.4 Family-Friendly Management Practices 036

2.4.1 Family-Friendly Management 036

2.4.1.1 Five Perspectives on Family-Friendly Management 037

2.4.2 Practices on Work-Family Balance and Its Impact on Balancing of Work and Family Life $\quad 040$

2.4.2.1 Organizational Practices on Work-Family Balance and its impact on it.

2.4.2.2 Employees Practices on Work-Family Balance a 
and its impact on it.

2.4.2.3 Government Practices on Work-Family Balance

and its impact on it

2.4.3 Family-Friendly Arrangements in Firms in

Australia, Japan, the United Kingdom and the United States 061

$\begin{array}{lll}2.5 & \text { Managerial roles } & 062\end{array}$

$\begin{array}{lll}2.6 & \text { Summary } & 067\end{array}$

\section{CHAPTER 3: RESEARCH METHODOLOGY}

$\begin{array}{lll}3.1 & \text { Introduction } & 068\end{array}$

3.2 Nature of the Research 068

$\begin{array}{ll}3.3 & \text { Unit of Analysis } \\ \end{array}$

$\begin{array}{lll}3.4 & \text { Type of Investigation } & 069\end{array}$

$\begin{array}{lll}3.5 & \text { Selection of Respondents } & 070\end{array}$

3.6 Data Collection and Analysis Method 070

$\begin{array}{ll}\text { 3.6.1 Thick description } & 070\end{array}$

3.6.2 Triangulation 071

$\begin{array}{lll}3.6 .3 & \text { Observation } & 071\end{array}$

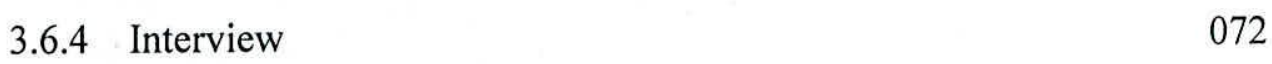

$\begin{array}{ll}\text { 3.6.5 Third Party Information } & 075\end{array}$

$\begin{array}{lll}\text { 3.6.6 Case Study } & 075\end{array}$

$\begin{array}{lll}3.7 & \text { Study Setting } & 076\end{array}$

$\begin{array}{lll}3.8 & \text { Time Horizon } & 077\end{array}$ 
3.9 Extent of Research Interference 078

$\begin{array}{lll}3.10 & \text { Summary } & 078\end{array}$

\section{CHAPTER 4 :DATA PRESENTATION}

$\begin{array}{lll}4.1 & \text { Introduction } & 079\end{array}$

4.2 Face-to-Face Interview Presentation 079

$\begin{array}{lll}\text { 4.2.1 } & \text { Manager } 01 & 079\end{array}$

4.2.1.1 Profile of the respondent 079

$\begin{array}{ll}\text { 4.2.1.2 Content } & 080\end{array}$

4.2.2 Manager $02 \quad 084$

4.2.2.1 Profile of the respondent 084

$\begin{array}{ll}\text { 4.2.2.2 Content } & 084\end{array}$

$\begin{array}{lll}\text { 4.2.3 Manager } 03 & 087\end{array}$

4.2.3.1 Profile of the respondent 087

$\begin{array}{ll}\text { 4.2.3.2 Content } & 087\end{array}$

$\begin{array}{lll}\text { 4.2.4 Manager } 04 & 090\end{array}$

4.2.4.1 Profile of the respondent 090

$\begin{array}{ll}\text { 4.2.4.2 Content } & 091\end{array}$

4.2.5 Manager 05

4.2.5.1 Profile of the respondent 093

$\begin{array}{ll}4.2 .5 .2 \text { Content } & 094\end{array}$

$\begin{array}{lll}\text { 4.2.6 Manager } 06 & 097\end{array}$

4.2.6.1 Profile of the respondent 097

$\begin{array}{ll}\text { 4.2.6.2 Content } & 098\end{array}$ 
4.2.7.1 Profile of the respondent

101

4.2.7.2 Content

101

4.2.8 Manager 08

104

4.2.8.1 Profile of the respondent 104

4.2.8.2 Content

105

4.2.9 Manager 09

108

4.2.9.1 Profile of the respondent 108

4.2.9.2 Content

109

4.2.10 Manager 10

111

4.2.10.1Profile of the respondent

4.2.10.2Content

4.2.11 Manager 11

4.2.11.1Profile of the respondent

4.2.11.2Content

4.2.12 Manager 12

4.2.12.1Profile of the respondent

4.2.12.2Content

4.2.13 Manager 13

4.2.13.1Profile of the respondent 
$\begin{array}{ll}\text { 4.2.15 Manager } 15 & 128\end{array}$

4.2.15.1Profile of the respondent 128

$\begin{array}{ll}4.2 .15 .2 \text { Content } & 128\end{array}$

4.2.16 Manager $16 \quad 130$

4.2.16.1Profile of the respondent 130

4.2.16.2Content 131

4.2.17 Manager $17 \quad 133$

4.2.17.1Profile of the respondent 133

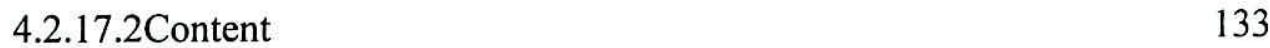

4.2.18 Manager 18

4.2.18.1Profile of the respondent 136

$\begin{array}{ll}\text { 4.2.18.2Content } & 137\end{array}$

4.2.19 Manager 19

4.2.19.1Profile of the respondent 139

$\begin{array}{ll}4.2 .19 .2 \text { Content } & 140\end{array}$

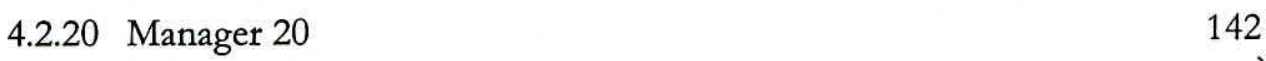

4.2.20.1Profile of the respondent -142

4.2.20.2Content 142

4.2.21 Manager 21 144

4.2.21.1Profile of the respondent 144

$\begin{array}{ll}4.2 .21 .2 \text { Content } & 145\end{array}$

$\begin{array}{ll}\text { 4.2.22 Manager } 22 & 147\end{array}$

4.2.22.1Profile of the respondent $\quad 147$

$\begin{array}{ll}4.2 .22 .2 \text { Content } & 148\end{array}$ 
4.2.36.1Profile of the respondent

4.2.37.1Profile of the respondent 